\title{
Growth, Nutrient Content and SPAD Value of Corn in Monoculture and in Intercropping
}

\author{
Anna Christina Sanazário de Oliveira*, Fábio Cunha Coelho, Henrique Duarte Vieira, \\ Jocarla Ambrosim Crevelari, Raquel Fialho Rubim \\ Laboratório de Fitotecnia, Universidade Estadual do Norte Fluminense, Campos dos Goytacazes, Brasil \\ Email: annasanazario@gmail.com
}

Received 16 June 2014; revised 19 July 2014; accepted 7 August 2014

Copyright (C) 2014 by authors and Scientific Research Publishing Inc.

This work is licensed under the Creative Commons Attribution International License (CC BY). http://creativecommons.org/licenses/by/4.0/

c) (i) Open Access

\section{Abstract}

The objective of this study was to evaluate the growth, the nutrition, and the intensity of the green color in corn plants in monoculture and in intercropping with Mucuna aterrima, Crotalaria juncea, and Canavalia ensiformis, cultivated with different handlings. In general, corn plants in monoculture demonstrated greater growth and greater SPAD value in the first evaluation, despite presenting lower tenor of phosphorus in the leaves when related to the corn in intercropping. The weed helps in the growth of the corn plant and increases the SPAD value during flowering. The monoculture NPK (Nitrogen, Phosphorus and Potassium) fertilization promoted higher values in corn plant growth, as well as a greater SPAD value, at 30 d.a.e., of the plants. The NPK-fertilized corn plants showed a greater tenor of sulphur and a lower tenor of molybdenum. The corn in intercropping with $M$. aterrima resulted in smaller plants at 70 d.a.e. It also presented a greater tenor of molybdenum and lower tenor of nickel when compared to intercroppings with $C$. juncea and with $C$. ensiformis. The corn plants in a intercropping with Crotalaria juncea presented higher growth at 30 and 70 d.a.e. and greater tenors of molybdenum when compared to the plants in intercropping with $C$. ensiformis.

\section{Keywords}

Zea mays, Green Manure, Intensity of the Green Color

\section{Introduction}

Corn is a cereal originated from Central America and cultivated throughout Brazil. It has high economic importance because of its different uses, ranging from human and animal feeding to the high technological industry.

${ }^{*}$ Corresponding author. 
Due to its great economic importance, there are many jobs that deal with practices aiming at the sustainability of the handling of agricultural soil. Amongst them is the use of green fertilizers, which may or may not be incorporated to soil in rotation, succession or intercropping with different cultures.

The green fertilization has the purpose of preserving or restoring the productivity of agricultural lands. Green fertilizations have been used to improve the physical and chemical characteristics of the soil and to increase the productivity of several cultures. The contribution in fertility improvement in soil by the supply of nutrients is one of the expected qualities by the application of green fertilization, e.g., the Fabaceae, which can contribute with fixed nitrogen, increasing and conserving the nitrogen in the soil [1].

The usage of green fertilization produces residues, recycles and mobilizes leachate or little soluble nutrients from deep soil layers, which benefit some aspects of soil fertility, such as the organic matter tenor and the production of organic acids, the tenor of $\mathrm{Al}$, the availability of nutrients such as $\mathrm{Ca}$, $\mathrm{Mg}$, and $\mathrm{K}$ and the capability of cation exchange.

The species from the Fabaceae family are the most used as green fertilizers, since they fix the nitrogen biologically, in association with diazotrophic bacteria. In addition, they produce large quantities of dry matter with high concentration of nutrients in the aerial part, they have a deep and branched root system and they also allow for an easy decomposition [2].

Nitrogen is one of the most limited nutrients for the achievement of high corn productivity [3]. The nutrient participates with four atoms in the chlorophyll molecule and it is a component in nucleic acids and hormones. In addition, it is indispensable for the constitution of proteins and, because of that, it is directly related to plant growth [4].

Chlorophyll is a pigment that reflects the green color in plants and is directly associated with the potential of the photosynthetic activity, as well as with the nutritional status of plants [5]. This pigment can be measured using the SPAD index and, after analysis, the level of nitrogen in the plant can be evaluated. According to [6], this equipment can also allow the synchronization of nitrogen application with the season of nutrient demand by the plant. Moreover, in corn culture, the associations between chlorophyll meter reading and grain income are currently under study.

The nutritional status of plants is generally evaluated by the chemical analysis of the plant tissue. It has as applications the identification of nutritional disabilities and the prediction of the need for nutrient supply. Other resources can be used to help in the evaluation of the nutritional status of plants, such as the use of a SPAD-502 chlorophyll meter to determinate the relative chlorophyll index [7].

The aim of this study was to evaluate the growth, the nutrition and the intensity of the green color in corn plants in different cultures: in monocultures and in intercroppings with three different Fabaceae.

\section{Material \& Methods}

The experiment was conducted during spring and summer 2011 and 2012, in a Haplic, Silt Loam Cambisol with $10 \%$ sand, $77.2 \%$ silt, and $12.8 \%$ clay, in which the chemical characteristics were analyzed, ranging from the depth of 0 to $20 \mathrm{~cm}$, according to [8] (Table 1).

The evaluated treatments were: corn in monoculture with NPK fertilization in sowing and with weed on corn haystack in monoculture with NPK fertilization in sowing and with weed (T1); corn in monoculture without NPK fertilization in sowing and with weed on corn haystack in monoculture without NPK fertilization in sowing and with weed (T2); corn in monoculture with NPK fertilization in sowing without weed on corn haystack in monoculture with NPK fertilization in sowing without weed (T3); corn intercropping + Mucuna aterrima on

Table 1. Values of chemical characteristics of soil material on the occasion of the installation of the experiment (2011).

\begin{tabular}{ccccccc}
\hline $\mathrm{pH}$ & $\mathrm{P}^{*}\left(\mathrm{mg} \cdot \mathrm{dm}^{-3}\right)$ & $\mathrm{K}^{*}\left(\mathrm{mg} \cdot \mathrm{dm}^{-3}\right)$ & $\mathrm{Ca}\left(\mathrm{cmol}_{\mathrm{c}} \cdot \mathrm{m}^{-3}\right)$ & $\mathrm{Mg}\left(\mathrm{cmol}_{\mathrm{c}} \cdot \mathrm{dm}^{-3}\right)$ & $\mathrm{Al}\left(\mathrm{cmol}_{\mathrm{c}} \cdot \mathrm{dm}^{-3}\right)$ \\
\hline 5.9 & 4 & 69 & 6.3 & 3.9 & 0.0 \\
\hline $\mathrm{H}+\mathrm{Al}\left(\mathrm{cmol}_{\mathrm{c}} \cdot \mathrm{dm}^{-3}\right)$ & $\mathrm{Na}\left(\mathrm{cmol}_{\mathrm{c}} \cdot \mathrm{dm}^{-3}\right)$ & $\mathrm{S} . \mathrm{B} .\left(\mathrm{cmol}_{\mathrm{c}} \cdot \mathrm{dm}^{-3}\right)$ & $\mathrm{T}\left(\mathrm{cmol}_{\mathrm{c}} \cdot \mathrm{m}^{-3}\right)$ & $\mathrm{T}\left(\mathrm{cmol}_{\mathrm{c}} \cdot \mathrm{dm}^{-3}\right)$ & $\mathrm{MO}(\mathrm{g} \cdot \mathrm{m})$ \\
\hline 4.3 & 0.37 & \multicolumn{2}{c}{10.7} & 15.0 & 10.7 & 30.5 \\
\hline $\mathrm{C}(\%)$ & $\mathrm{M}(\%)$ & $\mathrm{V}(\%)$ & $\mathrm{Fe}\left(\mathrm{mg} \cdot \mathrm{dm}^{-3}\right)$ & $\mathrm{Cu}\left(\mathrm{mg} \cdot \mathrm{dm}^{-3}\right)$ & $\mathrm{Zn}\left(\mathrm{mg} \cdot \mathrm{dm}^{-3}\right)$ & $\mathrm{Mn}\left(\mathrm{mg} \cdot \mathrm{dm}^{-3}\right)$ \\
\hline 1.77 & 0.0 & 71 & 61.2 & 3.1 & 4.0 & 22.2 \\
\hline
\end{tabular}

*Extractor North Carolina. 
haystack of corn intercropping (T4); corn intercropping + Crotalaria juncea on corn intercropping haystack (T5); corn intercropping + Canavalia ensiformis on corn intercropping haystack (T6).

The experiment was installed without the usage of herbicide in a direct plantation system, in which the treatments were placed on haystack of similar treatments. To that end, the plants of the previous cycle, which were already dry, were rubbed and left in their original experimental units. After that, the grooves were prepared with the help from a furrower and a tractor, for the sowing of the treatments.

A randomized-block design, with four repetitions, was chosen for the experiment.

Each experimental unit (U.E.) of the corn monoculture was constituted by five lines with five meters, with a space of a meter between each one. The U.E. of the intercroppings were constituted by five ranks of corn interspersed by four ranks of Fabaceae with five meters in length, spaced by one meter and having three central lines of corn as an useful area, discarding fifty centimeters in their ends.

The used corn cultivar was the UENF 506/11 interpopulational hybrid.

The soil analysis was carried out to determine fertilization. The applied doses of NPK were of $80-80-20$ $\mathrm{kg} \cdot \mathrm{ha}^{-1}$, using single superphosphate and potassium chloride, respectively, as sources of ammonium sulfate. The single superphosphate and the potassium chloride were applied in their totality, along with $2 / 3$ of the ammonium sulfate dose, immediately before sowing. The rest of $\mathrm{N}$ was applied in fertilization of coverage. This fertilization was done only in corn in monoculture for treatments T1 and T3, in both cultivar cycles.

The nitrogen coverage fertilization was conducted seventeen days after emergence (d.a.e.) on treatments T1 and T3. At this time, the corn plants displayed six to eight leaves. Since the corn plants were too little in other treatments, it was decided to carry out the coverage fertilization with the same dose used in treatments T1 and T3, also at 29 d.a.e.

In corn sowing, C. juncea and C. ensiformis, ten, fifteen, and four seeds were used, respectively, for each linear meter. The corn plants were thinned when they achieved a number between six and eight leaves, leaving a population corresponding to 50,000 plants per hectare. The inoculation was carried out with innoculants containing the Bradyrhizobium sp. strains (BR 2003) for C. juncea and B. elkanii (BR 2811) for C. ensiformis, which were provided by EMBRAPA Agrobiology. It was conducted according to the method suggested by EMBRAPA Agrobiology.

At 30 d.a.e. and, afterwards, every 20 days, phenological evaluations were carried out in five corn plants marked in each usable area. These evaluations were done until the plant reached senescence. Thus, the plant height was determined: the measurement from its lap to the insertion of the last leaf; the number of leaves was determined: the green and developed ones were counted; the diameter of the thatch: the biggest diameter of the stem; the length of the leaf was determined: the biggest one was measured; and the width of the leaf was also measured: the biggest one was measured.

For the nutritional analysis of corn, ten leaves were collected in each usable area during the corn R5 status, which is a period when the ears expose the styles-stigmas. The collected leaf was the one opposite to and under the ear; a medium third was used, with the exclusion of the central vein.

The samplers of the collected plant tissues were identified and taken in paper bags to the greenhouse with forced air circulation, where they stayed for 72 hours at a temperature of $65^{\circ} \mathrm{C}$; afterwards, they were grinded in a Willey mill by using a sieve with 20 meshes per inch.

The tenors for organic N, P, K, Ca, Mg, S, Mn, Zn, Fe, Cu, B, Mo, and Ni of corn plant leaves were determined for every treatment.

The tenors of N, P and K were determined by the extract of the sulphuric digestion, and the organic N, by the colorimetric method with Nessler's reagent [9]. P was determined by colorimetry, using ammonium molybdate; $\mathrm{K}$ was determined by the emission in spectrophotometer. The other nutrients were determined by the extract of the nitropercloric digestion. $\mathrm{Ca}, \mathrm{Mg}, \mathrm{Zn}, \mathrm{Cu}, \mathrm{Mn}$, and Fe were quantified by spectrophotometry of atomic absorption. $\mathrm{S}$ was quantified by turbidimetry, using $\mathrm{BaCl}_{2}$ and arabic gum [10].

Mo and Ni were determined by spectrophotometry of atomic absorption with graphite furnace after dry via digestion. Five hundred milligrams of dry and milled vegetal material were weighed in bottles of $10 \mathrm{~mL}$. These bottles were taken to the muffle at $550^{\circ} \mathrm{C}$ during 4 hours. After cooling, the samples were removed from the muffle, and in each bottle, $2 \mathrm{~mL}$ of $\mathrm{HNO}_{3}$ at $2 \%$ and put in sand bath at $180^{\circ} \mathrm{C}$, until the material was completely dry. Then, $10 \mathrm{~mL}$ of $\mathrm{HNO}_{3}$ at $0.5 \%$ was added, and the samples were shaken and transferred to test tubes with $15 \mathrm{~mL}$ and centrifuged at $2800 \mathrm{rpm}$ during six minutes. The extracts were used for reading.

Two measurements were done on the intensity of the green color, with help from the SPAD-502 Minolta 
Chlorophyll equipment, on the most developed leaf of three corn plants, randomly chosen during the first evaluation. These measurements were done at 30 d.a.e. and during flowering.

An analysis of data variance was carried out and, on the variables with significant effect $(P<0.05)$, the effect of orthogonal contrast was evaluated (Table 2).

The analyses were made with the aid of the software SAEG 9.0 (Systems for Statistical Analyses).

\section{Results \& Discussion}

At 30 d.a.e., the contrasts that evaluated the effects of cultivation (C1) and weeding system (C2) obtained high significance over the whole analyzed phenology, i.e., leaf height, number, length and width, and stem diameter of corn plants (Table 3).

Regarding the cropping system (C1) at 30 d.a.e., the corn in monoculture was better than the corn in intercropping in all variables. This occurred due to competition for light, water and nutrients between Fabaceae and corn, as stated by [11], showing the negative effects of the competition at the start of cultivation.

The weeded corn in monoculture presented higher values than the non-weeded for plant height and leaf length (C2) at 30 d.a.e. Even though [12] stated that early in the development cycle, the crop and the weeds can live for a certain period without incurring damage to the crop productivity, a period called "period before interference" (PAI), when the environment is capable of providing the necessary resources for the growth of the weed community and of the crop culture.

The corn in monoculture fertilized with NPK at the sowing stage showed higher values than the non-fertilized in all variables (C3) at 30 d.a.e. It can be stated that corn plants already had a response at 30 d.a.e., to the fertilizer applied at sowing, presenting plants with higher growth in height. Reference [13] found that the absence of fertilization with nitrogen also affected the growth of wheat plants.

During this period, there was no significant difference in any variable between corn plants in intercropping with M. aterrima when compared to other intercroppings (C4). However, when comparing the corn plants in intercropping to $C$. juncea and the corn plants in intercropping with $C$. ensiformis, differences were observed for the following variables: height, number, and length of corn plants (C5).

In the second growth evaluation, at 50 d.a.e., corn plants in monoculture were taller, and the number, length and width of leaves and stem diameters were larger than in the plants in intercropping (C1).

The same happened to the corn plants fertilized with NPK at sowing when compared to non-fertilized (C3). This corroborates with the results achieved by [14], who also found an increase in the vigor of corn with increasing levels of nitrogen.

During this period, the weed (C2) had no effect on corn plant height; however, it resulted in increases in the other variables analyzed.

Regarding the intercropping of corn with M. aterrima compared to other consortia (C4), the corn plants in intercropping with the $M$. aterrima had higher leaf length. As for the comparison between the corn plants in intercropping with $C$. juncea and in intercropping with $C$. ensiformis (C5), no significant difference was observed.

At 70 d.a.e., the monoculture (C1) and the NPK fertilization at sowing (C3), due to greater availability of NPK, showed increases in all variables (Table 3 ).

Despite the fact that the weeding (C2) did not influence the height of corn plants, this management interfered positively in the remaining variables.

Table 2. Orthogonal contrasts used for the statistic analysis of data.

\begin{tabular}{|c|c|}
\hline Contrast & Comparison \\
\hline $\begin{array}{l}\text { C1-Corn in monoculture (T1 + T2 + T3) versus corn in intercropping } \\
(\mathrm{T} 4+\mathrm{T} 5) \text {; }\end{array}$ & Compares monoculture with intercropping \\
\hline $\begin{array}{l}\mathrm{C} 2 \text {-Corn in monoculture with weed }(\mathrm{T} 1+\mathrm{T} 2) \text { versus corn in monoculture } \\
\text { without weed (T3); }\end{array}$ & Compares the effect of weed in monoculture \\
\hline $\begin{array}{l}\text { C3-Corn in monoculture with weed with complete fertilization (T1) versus } \\
\text { corn in monoculture with weed without complete fertilization (T2); }\end{array}$ & Compares the effect of fertilization in monoculture \\
\hline $\begin{array}{l}\text { C4-Corn in intercropping with } M \text {. aterrima (T4) versus corn in intercropping } \\
\text { with } C \text {. juncea and corn in intercropping with C. ensiformis (T5 + T6). }\end{array}$ & $\begin{array}{l}\text { Compares the effect of } M \text {. aterrima with other } \\
\text { intercroppings }\end{array}$ \\
\hline $\begin{array}{l}\text { C5-Corn in intercropping with C. juncea (T5) versus corn in intercropping } \\
\text { with C. ensiformis (T6). }\end{array}$ & $\begin{array}{l}\text { Compares the effects of } C \text {. juncea with the one of } \\
\text { C. ensiformis, in partnership with corn }\end{array}$ \\
\hline
\end{tabular}


Table 3. Estimations of orthogonal contrasts, the average per plot, for height of corn (ALT), number of leaves (NUF), leaf length (COF), width of leaves (LAF) and stem diameter (DIC), in four phases.

\begin{tabular}{|c|c|c|c|c|c|}
\hline Contrasts & $\operatorname{ALT}(\mathrm{cm})$ & NUF & $\mathrm{COF}(\mathrm{cm})$ & $\mathrm{LAF}(\mathrm{cm})$ & DIC (mm) \\
\hline & & & 30 d.a.e. & & \\
\hline $\mathrm{C} 1$ & $11.74^{* *}$ & $1.53^{* *}$ & $21.47^{* *}$ & $2.20^{* *}$ & $8.35^{* *}$ \\
\hline $\mathrm{C} 2$ & $-10.89^{* * *}$ & -0.15 & $-17.00^{* * *}$ & -0.20 & -0.66 \\
\hline C3 & $18.58^{* *}$ & $1.80^{* *}$ & $37.80^{* *}$ & $3.23^{* * *}$ & $14.19^{* *}$ \\
\hline $\mathrm{C} 4$ & -0.53 & 0.13 & -0.82 & -0.18 & -0.14 \\
\hline C5 & $5.85^{*}$ & $0.95^{* *}$ & $11.55^{*}$ & 0.95 & 3.49 \\
\hline \multirow[t]{2}{*}{ C.V. (\%) } & 23.97 & 9.96 & 15.48 & 23.68 & 23.80 \\
\hline & & & 50 d.a.e. & & \\
\hline $\mathrm{C} 1$ & $26.13^{* *}$ & $2.22^{*}$ & $7.68^{*}$ & $2.90^{*}$ & $6.65^{* *}$ \\
\hline $\mathrm{C} 2$ & -3.63 & $1.53^{* *}$ & $11.15^{*}$ & $4.10^{*}$ & $11.04^{* *}$ \\
\hline C3 & $56.75^{* *}$ & $2.95^{* *}$ & $12.60^{*}$ & $6.08^{* *}$ & $9.78^{* *}$ \\
\hline $\mathrm{C} 4$ & 2.03 & 0.60 & $7.73^{*}$ & 0.57 & 0.92 \\
\hline C5 & 11.85 & 1.10 & 7.15 & 0.30 & 3.64 \\
\hline \multirow[t]{2}{*}{ C.V. (\%) } & 23.81 & 13.24 & 10.54 & 43.39 & 60.43 \\
\hline & & & 70 d.a.e. & & \\
\hline $\mathrm{C} 1$ & $37.57^{* *}$ & $2.22^{*}$ & $7.68^{*}$ & $2.90^{*}$ & $6.65^{*}$ \\
\hline $\mathrm{C} 2$ & -7.97 & $1.53^{*}$ & $11.15^{*}$ & $4.10^{*}$ & $11.04^{* *}$ \\
\hline C3 & $102.35^{* *}$ & $2.95^{* *}$ & $12.60^{* *}$ & $6.08^{* *}$ & $9.78^{* *}$ \\
\hline $\mathrm{C} 4$ & $-38.58^{* *}$ & 0.60 & $7.73^{*}$ & 0.57 & 0.92 \\
\hline C5 & $18.95^{* *}$ & 1.10 & 7.15 & 0.30 & 3.64 \\
\hline \multirow[t]{2}{*}{ C.V. (\%) } & 10.43 & 12.06 & 10.35 & 33.27 & 18.00 \\
\hline & & & 90 d.a.e. & & \\
\hline $\mathrm{C} 1$ & $31.44^{* *}$ & 0.07 & $18.33^{* *}$ & $1.12^{*}$ & $4.03^{*}$ \\
\hline C2 & $17.96^{*}$ & $2.90^{*}$ & $25.19^{* *}$ & $2.70^{* *}$ & $8.14^{* *}$ \\
\hline C3 & $40.65^{* *}$ & $1.30^{*}$ & $18.05^{* *}$ & 0.38 & $4.18^{*}$ \\
\hline $\mathrm{C} 4$ & 9.97 & -1.20 & 7.86 & 0.66 & 0.86 \\
\hline C5 & 10.75 & 0.94 & 4.76 & 0.53 & 1.33 \\
\hline C.V. (\%) & 15.49 & 15.46 & 17.11 & 11.52 & 17.25 \\
\hline
\end{tabular}

"Significant at $5 \%$ probability; ${ }^{* *}$ Significant at $1 \%$ probability; ${ }^{\text {ns }}$ Not significant.

The contrast that confronts the corn $+M$. aterrima intercropping with the other consortia (C4) obtained significance at the corn plants height. Corn plants in intercropping with the $M$. aterrima showed up about $38 \mathrm{~cm}$ shorter than the average intercropped with the $C$. juncea and than the average intercropped with the $C$. ensiformis. The $M$. aterrima grew significantly and, by having an indeterminate growth habit and a climbing habit, this Fabaceae competed intensively for light with the corn, which certainly made corn plants grow less.

Corn plants in intercropping with $C$. juncea also showed higher values compared to the intercropped with $C$. ensiformis.

During the last evaluation, at 90 d.a.e., the monoculture (C1), the weed in corn monoculture (C2) and the sowing with NPK fertilizer (C3) showed significant effect on all variables, except for number of leaves in the cropping system and the leaf width for fertilization.

In this evaluation, there was no significant difference in any of the variables between the corn plants intercropped with $M$. aterrima comparing them with other consortia (C4) and the corn plants in intercropping with $C$. juncea and the corn plants intercropped with $C$. ensiformis (C5).

Table 4 shows, respectively, the estimates of orthogonal contrasts and the average of each treatment for macro 
Table 4. Estimations of orthogonal contrasts, of the average per plot, for macro and micronutrients in corn plants.

\begin{tabular}{|c|c|c|c|c|c|c|c|c|}
\hline \multirow{2}{*}{ Contrasts } & \multicolumn{8}{|c|}{ Macronutrients $\left(\mathrm{g} \cdot \mathrm{kg}^{-1}\right)$} \\
\hline & $\mathrm{N}^{\mathrm{ns}}$ & $\mathrm{P}$ & & $\mathrm{K}^{\mathrm{ns}}$ & & $\mathrm{Ca}^{\mathrm{ns}}$ & $\mathrm{Mg}^{\mathrm{ns}}$ & $\mathrm{S}$ \\
\hline $\mathrm{C} 1$ & -0.15 & $-0.36^{*}$ & & 1.33 & & 0.07 & 0.27 & 0.00 \\
\hline $\mathrm{C} 2$ & 1.01 & -0.09 & & -0.82 & & 0.24 & 0.08 & $-0.36^{* *}$ \\
\hline C3 & 0.91 & 0.15 & & -0.63 & & 0.02 & -0.61 & $0.23^{* *}$ \\
\hline C4 & 1.06 & 0.09 & & 1.38 & & 0.22 & $0.81^{* *}$ & -0.06 \\
\hline $\mathrm{C} 5$ & -0.09 & 0.04 & & -0.64 & & 0.20 & -0.20 & -0.05 \\
\hline C.V. (\%) & 15.36 & 9.90 & & 12.08 & & 8.54 & 15.79 & 8.48 \\
\hline \multirow{2}{*}{ Contrasts } & \multicolumn{8}{|c|}{ Micronutrients $\left(\mathrm{mg} \cdot \mathrm{kg}^{-1}\right)$} \\
\hline & $\mathrm{Mn}^{\mathrm{ns}}$ & $\mathrm{Zn}^{\mathrm{ns}}$ & $\mathrm{Fe}^{\mathrm{ns}}$ & & $\mathrm{Cu}^{\text {ns }}$ & $\mathrm{B}^{\mathrm{ns}}$ & Mo & $\mathrm{Ni}$ \\
\hline $\mathrm{C} 1$ & 1.92 & 2.79 & -74.75 & & -0.28 & 0.19 & $14.61^{*}$ & -25.60 \\
\hline $\mathrm{C} 2$ & 6.53 & 1.94 & 47.47 & & 1.05 & 0.15 & -319 & $-199.20^{* *}$ \\
\hline C3 & -2.35 & -0.17 & 90.20 & & 0.76 & -0.40 & $-43.52^{* *}$ & -13.20 \\
\hline $\mathrm{C} 4$ & 4.01 & -0.53 & 59.45 & & -0.04 & 0.32 & $32.56^{* *}$ & $-204.60^{* *}$ \\
\hline C5 & -0.55 & -0.74 & -38.32 & & -0.27 & 0.41 & $29.63^{* *}$ & -116.40 \\
\hline C.V. (\%) & 15.97 & 16.32 & 27.09 & & 19.73 & 15.52 & 19.90 & 18.04 \\
\hline
\end{tabular}

${ }^{*}$ Significant at $5 \%$ probability; ${ }^{* *}$ Significant at $1 \%$ probability; ${ }^{\text {ns }}$ Not significant.

and micronutrients in the leaves of corn plants. It can be seen that most of the nutrients showed no differences in the contrasts analyzed. This is due to the small difference between treatments; with the exception of nickel, which showed high values in all treatments (450 - $\left.1050 \mathrm{mg} \cdot \mathrm{kg}^{-1}\right)$, the tenors were suitable for the cultivation of corn, i.e., within the sufficiency range asserted by [15]: P: 15 to $40 \mathrm{mg} \cdot \mathrm{dm}^{3}, \mathrm{~K}: 1.5$ to $3.0 \mathrm{mmol} \cdot \mathrm{dm}^{3}, \mathrm{Ca}: 30$ to $50 \mathrm{mmol} \cdot \mathrm{dm}^{3}$, Mg 5 to $8 \mathrm{mmol} \cdot \mathrm{dm}^{3} \mathrm{~S} 11 \mathrm{dm}^{3}$ to $15 \mathrm{mg}, \mathrm{Zn}: 0.5$ to $1.0 \mathrm{mg} \cdot \mathrm{dm}^{3}$, B: 0.1 to $0.3 \mathrm{dm}^{3} \cdot \mathrm{mg}, \mathrm{Cu}: 0.4$ to $0.8 \mathrm{dm} \cdot \mathrm{mg}^{3}, \mathrm{Mn}$ : 3.0 to $5.0 \mathrm{mg} \cdot \mathrm{dm}^{3}$.

Despite the little difference, it can be observed that there was significance only for phosphorus content when taking into account the cropping system (C1), where intercropping corn had the highest values. It was expected that corn in monoculture would present higher levels of $\mathrm{P}$ than the intercropped, since two of the three treatments in monoculture received phosphate fertilizer at sowing and, in addition, the level of available $\mathrm{P}$ in the soil was low (Table 3). Reference [16] evaluated the cultivation of corn in monoculture and in intercropping with seven perennial legumes, and no differences were found between the different cropping systems.

The corn in monoculture, when compared to the intercropped variable, had higher molybdenum (C1) (Table 4). Certainly, the Fabaceae competed for this nutrient to the point of making it less available for the corn.

Also with little difference, the weed (C2) interfered with the sulfur content in weeded corn plants. However, in relation to the nickel content, this difference was higher, with higher values in weeded corn monoculture.

The corn in monoculture fertilized with NPK at sowing showed higher sulfur levels compared to the non-fertilized corn (C3). This is certainly due to the sulfur containing fertilizers used in its composition, thereby increasing the availability of this nutrient for the corn plants. However, lower molybdenum levels were checked in corn fertilized with NPK.

When comparing the levels of macro and micronutrients in corn in intercropping with M. aterrima and in corn of other consortia (C4), it can be seen that, on average, corn in intercropping with $M$. aterrima showed higher values of molybdenum, while the intercropping with $C$. juncea and $C$. ensiformis showed higher values of nickel. Additionally, the maize, when intercropped with $C$. juncea, showed higher concentrations of nickel than the intercropped with $C$. ensiformis (C5). These nutrients, despite needed by plants in small amounts, have crucial roles in the metabolism of nitrogen.

At 30 d.a.e., the cultivation system (C1) and the fertilization (C3) were significant on the intensity of green color, using SPAD value (Table 5).

The corn in monoculture showed higher intensity of the green color in the leaves than the intercropped corn. This possibly occurred because of the low contribution of Fabaceae in supplying $\mathrm{N}$ for intercropped corn in this short period of 30 days. 
Table 5. Estimations of orthogonal contrasts, of the average per plot, for the intensity of green color, using the SPAD value, of corn plants in two phases.

\begin{tabular}{ccc}
\hline Contrasts & 30 d.a.e. & Blossoming (90 d.a.e.) \\
\hline C1 & $14.72^{* *}$ & 1.38 \\
C2 & 0.35 & $11.13^{* *}$ \\
C3 & $15.51^{* *}$ & 8.03 \\
C4 & 0.80 & 0.30 \\
C5 & 0.99 & 2.71 \\
C.V. $(\%)$ & 15.60 & 20.61 \\
\hline
\end{tabular}

${ }^{*}$ Significant at $5 \%$ probability; ${ }^{* *}$ Significant at $1 \%$ probability; ${ }^{\text {ns }}$ Not significant.

The fertilization interfered with the SPAD value only during the initial stage (C3), as evidenced by [3] while working with C. ensiformis: it has been found that, with the addition of nitrogen, a more intense green color was verified in the leaves. It has to be emphasized that the treatment in monoculture corn (T1 and T3) also had, in addition to the fertilization at sowing, a covering with $2 / 3$ of the recommended $\mathrm{N}$, which possibly improved nutrition of the corn in monoculture. It is possible that this caused the plants in monoculture to get, on average, better nourished at this early stage.

The weed resulted in increased intensity of the green color in the leaves of corn during flowering (C2). Certainly, for the non-weeded corn in monoculture, the weeds competed for nutrients.

According to [17], the monitoring of the intensity of the green leaf color can assist in the evaluation of the availability of nitrogen (and this nutrient acts directly on vegetative growth). This can be confirmed in this study, since in the evaluations of the growth, the effects of culture system (monoculture-C1) and fertilization (C3) were positive (Table 5), as it was in the evaluations of the intensity of the green color.

No difference was observed between both evaluation periods, which contrasts the intensity of green color of corn plants intercropped with M. aterrima in comparison with those of other consortia (C4), as well as contrasting plants intercropped with $C$. juncea with the intercropped with C. ensiformis (C5). This shows that, taking into account only the intensity of the green color of the corn, the three Fabaceae have similar influences during the intercropping.

\section{Conclusions}

Generally, the corn plants in monoculture have a higher growth rate and a higher SPAD index at the beginning of cultivation, despite having less phosphorus in leaves than the intercropped corn.

The weed favors the growth of corn plants. Additionally, it increases the intensity of the green color during flowering.

The NPK fertilizer in monoculture promotes higher values in the growth of corn plants, as well as higher SPAD value at 30 d.a.e. of the plants. Corn plants fertilized with NPK have higher sulfur content and lower molybdenum content.

Corn intercropped with M. aterrima results in smaller plants at 70 d.a.e., in addition to showing higher molybdenum content and lower nickel content when compared to consortia with $C$. juncea and $C$. ensiformis.

Corn plants intercropped with $C$. juncea have higher growth at 30 and 70 d.a.e., and higher levels of molybdenum when compared to the ones intercropped with C. ensiformis.

\section{Acknowledgements}

To the "Fundação de Apoio e Amparo à Pesquisa of Rio de Janeiro" (FAPERJ) for the financial support of this project.

\section{References}

[1] Fontanétti, A., Carvalho, G.J., Gomes, L.A.A., Almeida, K., Moraes, S.R.G. and Teixeira, C.M. (2006) The Use of Green Manure in Crisphead Lettuce and Cabbage Production. Brazilian Horticulture, 24, 146-150. 
http://www.scielo.br/pdf/hb/v24n2/04.pdf

[2] Maia, F.E.N., Miranda, N.O., Melo, I.G.C., Viana, M.G.P. and Góis, S.R.P. (2013) C. ensiformis Biomass as a Function of Seeding Densities in Mossoró, RN, Brazil. ACSA-Agricultural Research in the Semi-Arid, 9, 43-49. http://150.165.111.246/ojs-patos/index.php/ACSA/article/viewFile/272/pdf

[3] Hurtado, S.M.C., Resende, A.V., Silva, C.A., Corazza, E.J. and Shiratsuchi, L.S. (2009) Spatial Variation of Corn Response to Nitrogen Topdressing in a Cerrado Crop Field. Brazilian Agricultural Research, 44, 300-309. http://www.scielo.br/pdf/pab/v44n3/v44n3a12.pdf

[4] Coelho, F.S., Fontes, P.C.R., Finger, F.L. and Cecon, P.R. (2012) Evaluation of Potato Nitrogen Status Based on Polyphenol and Chlorophyll Leaf Content. Brazilian Agricultural Research, 47, 584-592. http://www.scielo.br/pdf/pab/v47n4/47n04a15.pdf

[5] Zotarelli, L., Cardoso, E.G., Piccinin, J.L., Urquiaga, S., Boddey, R.M., Torres, E. and Alves, B.J.R. (2003) Calibration of a Minolta SPAD-502 Chlorophyll Meter for Evaluation of the Nitrogen Nutrition of Maize. Brazilian Agricultural Research, 38, 1117-1122. http://www.scielo.br/pdf/pab/v38n9/18291.pdf

[6] Rocha, R.N.C., Galvão, J.C.C., Teixeira, P.C., Miranda, G.V., Agnes, E.L., Pereira, P.R.G. and Leite, U.T. (2005) Relations between the Spad Index Determined by Chlrophyll Meter with Nitrogen Content in Leaves and Grain Yield in Maize Genotypes. Brazilian Journal of Maize and Sorghum, 4, 161-171.

http://rbms.cnpms.embrapa.br/index.php/ojs/article/view/137/135

[7] Tecchio, M.A., Moura, M.F., Paioli-Pires, E.J., Terra, M.M., Teixeira, L.A.J. and Smarsi, R. (2011) Nutrients Levels, Relative Chlorophyll Index and Concentration of Nitrate and of Potassium in the Petiole of Grapevine "Niagara Rosada”. Brazilian Journal of Tropical Fruits, 33, 649-659. http://www.scielo.br/pdf/rbf/v33n2/AOP04111.pdf

[8] EMBRAPA—Empresa Brasileira de Pesquisa Agropecuária (1997) Manual Methods of Soil Analysis. 2nd Edition, Rio de Janeiro.

[9] Jackson, M.L. (1965) Soil Chemical Analysis. Prentice Hall, Upper Saddle River.

[10] Malavolta, E., Vitti, G.C. and Oliveira, S.A. (1997) Assessment of Nutritional Status of Plants: Principles and Applications. 2nd Edition, POTAFOS, Piracicaba.

[11] Maciel, A.D., Arf, O., Silva, M.G., Sá, M.E., Rodrigues, R.A.F., Buzetti, S. and Bianchini Sobrinho, E. (2004) Common Bean Performance in Intercropping Corn-Common Bean in No Tillage System. Acta Scientiarum Agronomy, Maringá, 26, 273-278. file://C:/Users/kisan_000/Downloads/1827-5856-1-PB.pdf

[12] Silva, J.I.C., Martins, D., Pereira, M.R.R., Rodrigues-Costa, A.C.P., Costa, N.V. (2012) Determination of Weed Interference Periods in Sunflower Culture. Weed, 30, 27-36. http://www.scielo.br/pdf/pd/v30n1/v30n1a04.pdf

[13] Viana, E.M. and Kiehl, J.C. (2010) Rates of Nitrogen and Potassium on Growth of Wheat Plants. Bragantia, 69, 975982. http://www.scielo.br/pdf/brag/v69n4/v69n4a24.pdf http://dx.doi.org/10.1590/S0006-87052010000400024

[14] Valderrama, M., Buzetti, S., Benett, C.G.S., Andreotti, M. and Teixeira Filho, M.C.M. (2011) NPK Sources and Doses on Irrigated Corn under No-Till System. Tropical Agricultural Research, 41, 254-263. http://www.scielo.br/pdf/pat/v41n2/a15.pdf

[15] Fancelli, A.L. and Dourado, N.D. (2000) Production of Corn. Agropecuária, Guaíba.

[16] Queiroz, L.R., Coelho, F.C. and Barroso, D.G. (2007) Maize Crop in Alley Cropping System with Perennials Legumes. Science and Agrotechnology, 31, 1303-1309. http://www.scielo.br/pdf/cagro/v31n5/05.pdf

[17] Godoy, L.J.G., Souto, L.S., Fernandes, D.M. and Villas Boas, R.L. (2007) Use of Chlorophyll Meter in Nitrogen Fertilizing Management to Corn after Brachiaria decumbens Pasture. Rural Science, 37, 38-44. http://www.scielo.br/pdf/cr/v37n1/a07v37n1.pdf http://dx.doi.org/10.1590/S0103-84782007000100007 
Scientific Research Publishing (SCIRP) is one of the largest Open Access journal publishers. It is currently publishing more than 200 open access, online, peer-reviewed journals covering a wide range of academic disciplines. SCIRP serves the worldwide academic communities and contributes to the progress and application of science with its publication.

Other selected journals from SCIRP are listed as below. Submit your manuscript to us via either submit@scirp.org or Online Submission Portal.
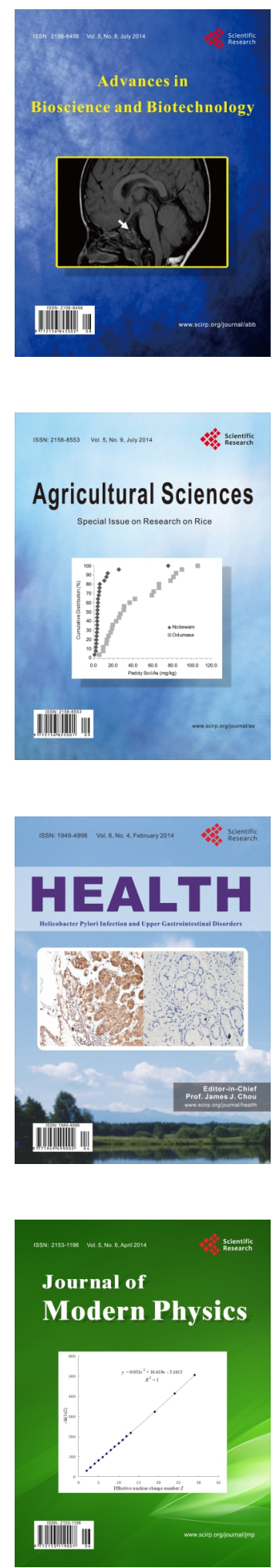
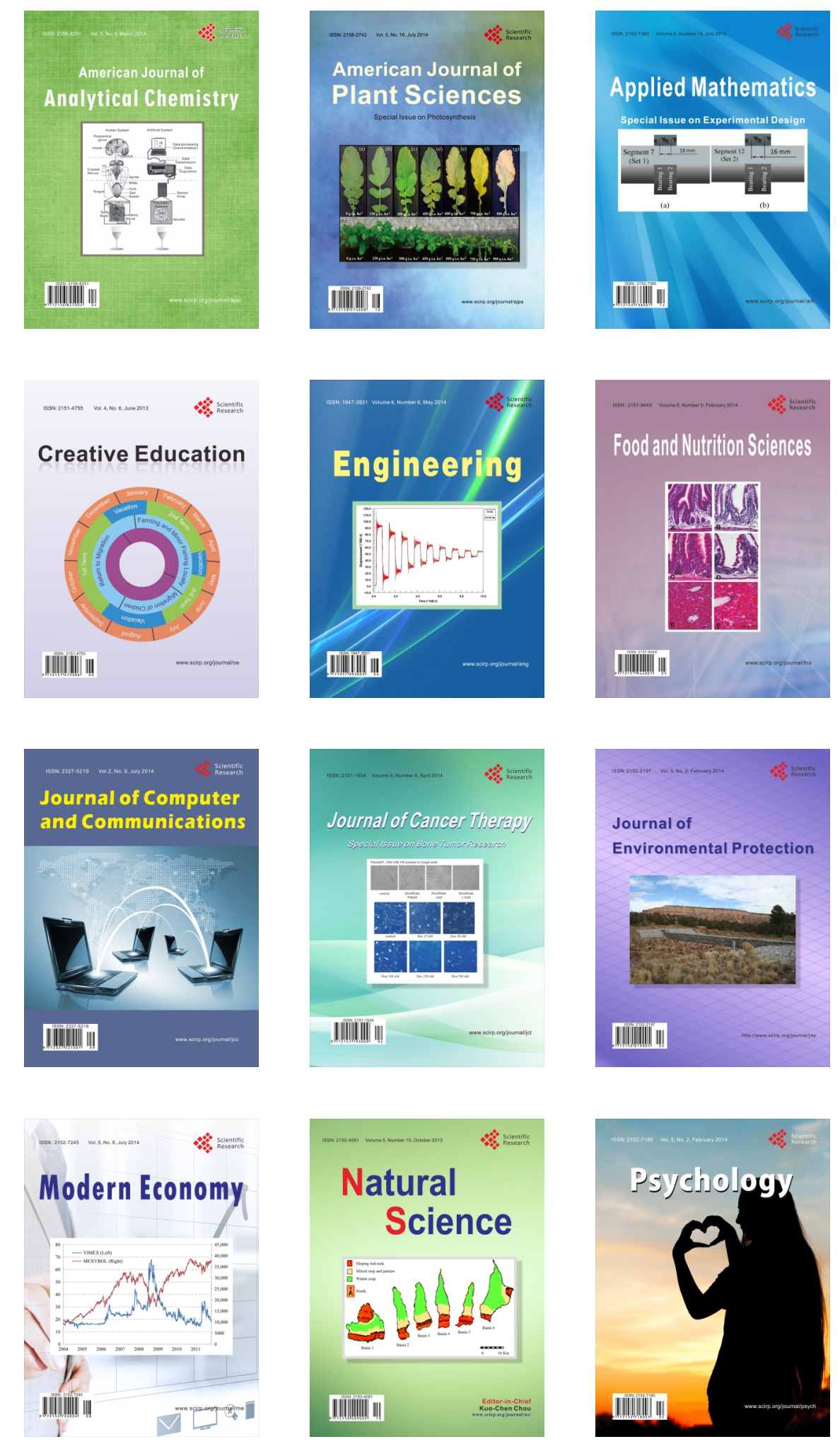